\title{
Rationaler som retfærdighedsregimer i kulturpolitikken
}

\author{
Nanna Kann-Rasmussen
}

\section{"Dortes kulturpolitiske rationaler"}

Et af Dorte Skot-Hansens væsentligste bidrag til den kulturpolitiske forskning er ideen om kulturpolitiske rationaler. Dortes rationaler, som det indforstået kaldes blandt kolleger på IVA, er blevet beskrevet og udviklet af Dorte Skot-Hansen i flere artikler, hvoraf to udgør grundlaget for denne artikels diskussion (Skot-Hansen, 1999, 2005). Mange kolleger i Norden, endnu flere i Danmark og utallige studerende har gennem årene brugt (og måske også misbrugt) dette begreb. Men hvad er egentlig et rationale, og hvordan kan man beskrive et rationale teoretisk? Det er omdrejningspunktet for denne tekst. I det følgende vil jeg derfor kort beskrive rationalerne som de fremstilles i de to nævnte artikler. Herefter vil jeg diskutere rationalebegrebet med begreber fra de franske sociologer Luc Boltanski og Laurent Thévenots pragmatiske sociologi.

\section{Kultur til tiden - Strategier i den lokale kulturpoli-} tik (Skot-Hansen, 1999) beskrives tre rationaler for den lokale kulturpolitik.

- Det humanistiske rationale, som er baseret på ideologiske / idealistiske argumenter har dannelse

Nanna Kann-Rasmussen, lektor ph.d.

Det Informationsvidenskabelige Akademi, Københavns Universitet, nanna.kann.rasmussen@hum.ku.dk som sit mål og demokratisering af kulturen som sin strategi.

- Det sociologiske rationale, der beskrives som mere politiserende. Dette rationale har frigørelse som sit mål og kulturelt demokrati som sin strategi.

- Endelig beskrives det instrumentelle rationale som har vægt på økonomiske argumenter. Dette rationale har synliggørelse (af fx byer og kulturinstitutioner) som sit mål og kulturalisering som sin strategi.

Artiklens store styrke er, at den udover at beskrive typen af argumenter også leverer en fyldig beskrivelse af, hvordan rationalerne folder sig ud i praksis. Således udstyres vi som læsere med viden om mål, baggrund, og kulturpolitiske strategier for rationalerne, men vi får også et billede af, hvordan publikum konstrueres (fx som grupper eller segmenter), vi får noget at vide om rammerne for formidlingen ( $\mathrm{fx}$ kulturinstitutioner eller flagskibe) og hvordan kulturformidlerne karakteriseres ( $\mathrm{fx}$ som animateur eller kaospilot).

I 2001-2005 var Dorte Skot-Hansen en del af et EU projekt - EUROCULT21. Dette projekt producerede bl.a. en rapport, hvori Skot-Hansens bidrag til rapporten hedder Why Urban Cultural Policies? I dette bidrag udvikles modellen over de tre kulturpolitiske rationaler til en ny model, modellen om de 4 E'er, Enlightenment, Empowerment, Entertainment og Economic Impact. I den nye model genfinder vi de tre rationaler fra 1999, (Det humanistiske er blevet til 
Enlightenment, Det sociologiske til Empowerment og Det instrumentelle til Economic Impact). Derudover introduceres underholdning som et fjerde rationale, Entertainment. Skot-Hansen viser her hvordan modellen kan anvendes på forskellige måder. For det første anvendes de til at beskrive rationalerne bag kulturpolitikken i byer. Det spørgsmål Skot-Hansen stiller er: med hvilket formål støttes kunst og kultur? For det andet bruges modellen til at beskrive kulturelle aktiviteter i byerne. I denne del af artiklen diskuterer Dorte hvilke aktiviteter der kan finde sted, fx som partnerskaber når der er flere rationaler på spil. Spørgsmålet der her stilles er: Hvordan former forskellige rationaler kulturelle aktiviteter? Et af eksemplerne i artiklen er lokale festivaler, som ligger i spændet mellem Empowerment og Entertainment. For det tredje anvendes de 4 E'er som baggrund for at introducere et modstykke - en ny type rationale nemlig det ekspressive rationale eller The fifth E": Experience. Det ekspressive rationale er i modsætning til de fire første rationaler ikke instrumentelt.

I artiklen beskrives det således, hvordan alle de fire første E'er er instrumentelle, selv Enlightenment og Empowerment, som i artiklen fra 1999 fremhæves som kontraster til det instrumentelle rationale. Det femte E, Experience fremhæver, at kunst og kultur er noget der giver vores liv meningsfuldhed og dybde.

Ikke bare når vi udsættes for den sublime kunst, men også når vi selv synger i badet, strikker en sweater eller deltager i en læsekreds. Det femte rationale knyttes til begrebet ekspressiv logik. Den ekspressive logik, som er modsætning til den instrumentelle logik, skal flytte vores fokus fra hvad kulturen $g ø r$ for samfundet og det enkelte individ til hvad kulturen betyder. Den ekspressive logik fremhæver kultur og kunst som noget der, på grund af den æstetiske oplevelse er værdifuldt i sig selv, "som noget der giver vores liv dybde og intensitet" (Skot-Hansen, 2006, p. $34)$.

\section{Hvad er et rationale?}

Ifølge Den danske ordbog (ordnet.dk) er et rationale et "sagligt underbygget grundlag for en bestemt opfattelse, beslutning, undersøgelse el.lign".. Skot-Hansen definerer ikke selv begrebet rationale, men kobler det til legitimeringen af kulturpolitikken $(1999$, p. 11, 2005, p.31) forstået på den måde, at rationalerne er legitimeringer af støtte til kunst og kultur. Ligeledes fremhæves det at rationalerne kan være implicitte eller eksplicitte.

De kulturpolitiske rationaler omtales desuden som noget "der ligger bag ved kulturpolitikken" (2006, p. 25). Men bagved rationalerne finder vi en "logik" (ibid.). Denne logik kan være enten instrumentel (kulturen bruges som instrument for noget andet end sig selv, fx oplysning, social forandring eller økonomisk vækst) eller ekspressiv (oplevelsen som et mål i sig selv).

I det følgende vil jeg prøve at undersøge hvordan man teoretisk kan begribe rationalerne. Jeg vil anvende Boltanski og Thévenots pragmatiske sociologi, nærmere bestemt teorien om retfærdighedsregimer. Dette er en teoridannelse jeg selv har haft glæde af at anvende, og som, i denne sammenhæng, er interessant, fordi den er udarbejdet af en af Bourdieus elever, delvis som en kritik af Bourdieus habitusbegreb. Regimerne er nemlig ikke forbeholdt aktører fra bestemte sociale felter men almengyldige og ikke afhængige af særlige kapitalformer eller habitus (Crone, 2008).

\section{Rationalet som retfærdighedsregime}

Boltanski og Thévenot udgav i 1991 bogen De la Justification: Les économies de la grandeur (Engelsk udgave: Boltanski \& Thévenot, 2006). I denne bog udvikler forfatterne med udgangspunkt i både empiriske undersøgelser og politisk filosofi seks "retfærdighedsregimer" eller "verdener", som formelt er uforenelige, eftersom de hver især anerkendes som universelle i de situationer, hvor deres gyldighed etableres. Forfatterne vil undersøge hvad der sker når vi skændes, argumenterer og kritiserer hinanden, og de konkluderer, at vi anvender en mangfoldig, men begrænset række af ækvivalens- eller retfærdighedsprincipper i diskussionerne. Vi har således at gøre med en almen grammatik over retfærdighedskompetencer, som mennesker anvender i diskussioner, eller andre situationer hvor der kan være flere forskellige forestillinger om ret og uret på spil. Derfor er regimerne interessante, også når det gælder rationaler og legitimeringer for kulturpolitikken.

Teorien handler, ligesom Dorte Skot-Hansens rationaler, om legitimeringer, argumenter og værdisættelse. Derfor kan vi nu forsøge os med at karakterisere 


\begin{tabular}{|l|l|l|}
\hline Navn & Nøgleord /legitimitet beror på & Relevante personer \\
\hline Inspirationsregimet & $\begin{array}{l}\text { Uafhængighed af andres anerkendelse. Krea- } \\
\text { tivitet, passion og forestillingsevne. Mangel } \\
\text { på objektive målekriterier }\end{array}$ & $\begin{array}{l}\text { Skønånder, kunstnere, gale mennesker (der } \\
\text { drømmer, gør oprør og har store oplevelser) }\end{array}$ \\
\hline Det domestiske regime & $\begin{array}{l}\text { Loyalitet, tradition, familie, gode manerer, } \\
\text { trofasthed }\end{array}$ & Familien, "faderen" \\
\hline Opinionsregimet & $\begin{array}{l}\text { Andres genkendelse og anerkendelse (ikke } \\
\text { egen selvagtelse) }\end{array}$ & Kendte, journalister, meningsdannere \\
\hline Borgerregimet & $\begin{array}{l}\text { Solidaritet, kollektivets interesser. Modsæt- } \\
\text { ning til individuelle interesser }\end{array}$ & $\begin{array}{l}\text { Ingen enkeltpersoner (undtaget repræsen- } \\
\text { tanter for grupper) }\end{array}$ \\
\hline Markedsregimet & Køb, salg, rigdom opportunisme & Købere og sælgere \\
\hline Det industrielle regime & Effektivitet, funktionalitet professionalisme & $\begin{array}{l}\text { Eksperter, effektive og produktive profes- } \\
\text { sionelle }\end{array}$ \\
\hline
\end{tabular}

kulturpolitiske rationaler som argumenter, der bruges til at retfærdiggøre en særlig kulturpolitik.

Selvom de seks regimer er formelt uforenelige, hævder Boltanski ikke at de ikke kan eksistere side om side. Boltanski er interesseret $i$ at undersøge de konflikter og spændinger der opstår når modsatrettede logikker artikuleres i det sociale rum (Held, 2011, p. 24). Et godt eksempel på en sådan spænding får vi, når vi iagttager kulturpolitikken.

Først må vi se på hvad det er for et felt vi har med at gøre. Når vi taler om kulturpolitik, orienterer argumenterne sig i sagens natur mod kunsten. Kunstfeltets traditionelle argument, kunst for kunstens egen skyld findes i inspirationsregimet, som fremhæver værdien af det som ikke kan måles eller verbaliseres, det følelsesmæssige, det bizarre, det geniale og unikke (Boltanski og Thévenot, 2006 p. 159ff)

Ligeledes kan man sige at når vi taler om kulturpolitik, så er det svært at komme uden om borgerregimet. I borgerregimet er det ikke det enkelte individ men kollektivet der er interessant. Således hører politik og de fleste politiske argumenter til borgerregimet, efter som politik principielt føres for hele befolkningsgrupper og ikke individer. Borgerregimet fremhæver det fælles, lige rettigheder og forening. Når mennesker forener sig opnås både fælleskab og frihed fra undertrykkelse som kommer fra selviske interesser (Boltanski og Thévenot, 2006 p. 185ff)

Vi kan altså forvente, at kulturpolitikkens rationaler karakteriseres af et mix af borgerregimets og af inspirationsregiments argumenter. Lad os prøve at ka- rakterisere de fem E'er ud fra Boltanski og Thévenots grammatik.

Enlightenment E'et beskriver Dorte Skot-Hansen med følgende nøgleord: indsigt, viden, dannelse og refleksion (Skot-Hansen, 2006). Genstandsfeltet er kulturarv og "den gode kunst". I dette rationale er der, som forventet både argumenter fra inspirationsog borgerregimet. Hovedvægten ligger dog på inspirationsregimet. Det vigtige er den gode kunst. Kunsten besidder inspirationsregimets karakteristika og kan være genial, bizar og uhåndterlig. I den kulturpolitiske strategi, demokratisering af kulturen, anskues kunsten som et middel der kan tilføre befolkningen indsigt, viden og dannelse. Kunsten bruges altså i folkets tjeneste, og derfor er borgerregimet også på spil her.

Empowerment E'et gives nøgleordene identitet, inklusion, sammenhoengskraft og diversitet. Offentlig støtte til kunst og kultur legitimeres også her gennem et ønske på hele befolkningsgruppers vegne. Dog er den kulturpolitiske strategi der knytter sig til dette rationale kulturelt demokrati. Kulturpolitikken skal fremme folks muligheder for at udtrykke sig selv. Der er en substantiel forskel mellem demokratisering af kulturen og kulturelt demokrati (læs fx Skot-Hansen, 1999, 2005, 2006), men hvis man udelukkende anvender Boltanski og Thévenots begreber, er det svært at se forskel på argumentationen i strategierne. Begge trækker på inspirationsregimet og på borgerregimet. Dog er borgerregimet stærkere her. De kulturelle og kunstneriske udfoldelser måles primært ud fra deres frigørende potentiale. Således er både Enlightenment E'et og Empowerment E'et et mix af 
borger- og inspirationsregimet, men med forskellig vægt.

Entertainment E'et gives følgende nøgleord: afslapning, leg, sjov og rekreation. Det er svært at se et tydeligt kulturpolitisk rationale her. Entertainment E'et udtrykker snarere en empirisk iagttagelse af "markedets kapitalisering af vores behov for leg og afslapning" (Skot-Hansen, 2006, s. 33). Når offentlige kulturinstitutioner lader sig "kapitalisere" legitimeres det gennem opinionsregimet. I Opinionsregimet er legitimitet, i modsætning til i inspirationsverdenen, fuldstændig afhængig af andres anerkendelse. Det højeste mål er anerkendelse, uafhængigt at hvem der anerkender eller hvorfor. I forhold til kulturinstitutioner er opinionsverdenen interessant når man fx legitimerer sig ved brugerundersøgelser, og argumenterer for sit værd ved fx at fremhæve hvor langt man "når ud" (Kann-Rasmussen, 2016, Boltanski og Thévenot, 2006:180). Derfor kan man sige at Entertainment E'et introducerer et nyt legitimeringsregime, som supplerer inspirationsregimet, men skubber borgerregimet ud.

Economic Impact E'et får nøgleordene image, turisme, tilfyttere og jobskabelse. Rationalet her er at bruge kulturen som løftestang for økonomisk vækst. Inden for dette E er inspirationsregimet helt forsvundet. Derimod legitimeres kulturpolitikken i forventningen om økonomiske følgevirkninger. Her er det således markedsregimets argument der er på spil. I markedsregimet er køb, salg og profit alfa og omega. Problemet for kulturpolitikken er, som Skot-Hansen $(2005,2006)$ da også beskriver, at det er svært, for ikke sige umuligt at dokumentere sammenhængen mellem kulturen og den økonomiske vækst.

\section{Experience E'et beskriver Dorte Skot-Hansen som} det rationale der står over de andre rationaler (2006, p. 34). Oplevelsesrationalet eller den ekspressive logik legitimerer kunst og kultur fordi de giver os ople- velser som er meningsfulde og giver vores liv dybde og intensitet. I Boltanski og Thévenots optik er det her det rene inspirationsregime der argumenterer. Experience E'et ser Dorte som en modsætning til de fire andre rationaler, fordi det ikke er instrumentelt. Men i Boltanski og Thévenots optik er dette ikke den vigtige forskel. Derimod kan man sige at dette regime adskiller sig fra de andre regimer, fordi det ikke kombineres med andre argumenter. Inspirationsregimet insisterer på at noget godt kan give mening selvom det ikke kan måles eller objektiviseres.

To regimer kommer ikke i spil $\mathrm{i}$ analysen af de frem E'er. Det er det industrielle regime og det domestiske regime. Det domestiske regime er med sit fokus om familie, tradition og hierarki langt fra kulturpolitikkens genstandsfelt. Det industrielle regime, som fokuserer på professionalisme og effektivitet kan man godt finde i kulturinstitutionernes praksis (NPM), men som argument for tildeling af offentlig støtte til kunst og kultur er det mindre relevant.

Hvad kan denne lille analyse bidrage med? Boltanski og Thévenots regimer nuancerer de argumenter der kæmper om magten i rationalerne. De viser at der er flere argumenter på spil, og tydeliggør derved hvordan kulturpolitik i sagens natur er "det umuliges kunst". Ligeledes belyser anvendelsen af regimerne hvorfor det ekspressive oplevelsesrationale adskiller sig fra de andre rationaler. Det er nemlig som det eneste ikke sammensat af flere forskellige typer af argumenter. Vi tiltrækkes af oplevelsesrationalet som det rene argument.

På den anden side kan regimerne - hvis de skal give mening som kulturpolitisk analyseinstrument ikke stå alene. I en analyse af kulturpolitikken må vi altid iagttage argumenternes karakter, men også deres effekter i kulturfeltet og i samfundet som helhed. Dortes rationaler står distancen, fordi de er empirisk

\begin{tabular}{|l|c|c|c|c|c|}
\hline $\begin{array}{l}\text { Rationale/ } \\
\text { Retfardighedsregime }\end{array}$ & Enlightenment & Empowerment & Entertainment & Economic impact & Experience \\
\hline Inspiration & $\mathrm{X}$ & $\mathrm{X}$ & $\mathrm{X}$ & & $\mathrm{X}$ \\
\hline Borger & $\mathrm{X}$ & $\mathrm{X}$ & & & \\
\hline Opinion & & & $\mathrm{X}$ & $\mathrm{X}$ & \\
\hline Marked & & & & $\mathrm{X}$ & \\
\hline Industri & & & & & \\
\hline
\end{tabular}


funderede. De er udviklet med en solid viden om deres genstandsfelt.

\section{Referencer}

Boltanski, L \& Thévenot, L (2006). On Justification: Economies of Worth. Princeton and Oxford: Princeton University Press.

Boltanski, L \& Thévenot, L (2011). Den kritiske evnes sociologi. I: Held, L. (red) Luc Boltanski Pragmatisk Sociologi: en tekstsamling. København: Hans Reitzels forlag. 41-67.

Crone, $\mathrm{M}$ et al (2008). Introduktion: Luc Boltanskis virke og værk. Dansk Sociologi Nr. 2/19. årg. 2008 s. 7-11.

Held, L (2011). Introduktion til Luc Boltanskis sociologi. I: Held, L. (red) Luc Boltanski Pragmatisk
Sociologi: en tekstsamling. København: Hans Reitzels forlag. 7-40.

Kann-Rasmussen, N (2016). For samfundets skyld: Kulturlederes forestillinger om legitimitet og omverden. Nordisk Kulturpolitisk Tidsskrift (in press).

Skot-Hansen, D (1999). Kultur til tiden - Strategier i den lokale kulturpolitik. Nordisk Kulturpolitisk Tidsskrift, nr.1, p. 7-27.

Skot-Hansen, D (2005). Why Urban Cultural Policies? In: EUROCULT21 Integrated Report (Jill Robinson, Ed.). Helsinki: EUROCULT21, Eurocities, p. 31-40.

Skot-Hansen, D (2006). Biblioteket i kulturpolitikken - mellem instrumentel og ekspressiv logik. In: L. Emerek, C. Hvenegaard Rasmussen \& D. SkotHansen (red.), Folkebiblioteket som forvandlingsrum. Copenhagen: Danmarks Biblioteksforening \& Danmarks Biblioteksskole, p. 25-40. 